\title{
Evolution of Arbitration In India:- A study with reference to Ar-bitration And conciliation act 1996
}

\author{
Mr. Milind Chopra \\ Student, Symbiosis Law School, Nagpur \\ DOI: 10.29322/IJSRP.11.12.2021.p12013 \\ http://dx.doi.org/10.29322/IJSRP.11.12.2021.p12013
}

\begin{abstract}
Arbitration is a form of alternative dispute resolution, in which the parties give their free consent to have their dispute put before a neutral third party, known as the arbitrator, who then decides on the issue and comes to a conclusion, however, these rewards can be challenged and the remedy for this lies under section 34 (2) which lays down grounds for challenging the arbitral award.
\end{abstract}

There are certain disputes that cannot be decided by way of arbitration, disputes such as criminal cases have to be decided upon, only by the courts respectively.

With changing time, there is a larger need for such mechanisms which mark a departure from the rigorous court process, In India, courts are overburdened and resolution of matters is in progress for many in the meantime, therefore these alternative mechanisms provide for another platform where people can get certain matters resolved, without going through the rigorous regular court procedure.

Arbitration process in India is dealt with under the Arbitration and conciliation act 1996.

Though arbitration provides for a promising new hope, it is not yet that successfully embedded in the mindset of the society, there are many who still prefer courts over arbitration, their lack of awareness prevents them from availing the benefits inferred by the alternative mechanisms.

There are many challenges in the way of arbitration's complete acceptance, mostly the thinking of the society and the laws in existence for the same, play a major role.

Arbitration and Conciliation amendment act 2015 amends section 2 (2), broadens the scope of it by drawing a line and specifying the sections that would be applicable to international commercial arbitration as well.

Section 14 is also amended, this amendment bridges the gap between the earlier section and the amended one, the earlier section only provided for termination of the arbitrator, but the amended section also provides for substitution of the terminated arbitrator, by another.

The 2019 amendment act, introduced the term arbitral institution, provided for the respective courts which would designate these arbitral institutions, these institutions are to be graded by the Arbitration Council of India, the function of this particular council is also laid down and the criteria and factors for grading of the arbitral institutions are also mentioned, in addition, general norms for arbitrators are also laid down respectively.

The 2021 amendment act proposes the qualification of arbitration to be prescribed by the arbitration Council, it also

This publication is licensed under Creative Commons Attribution CC BY

http://dx.doi.org/10.29322/IJSRP.11.12.2021.p12013 provided for unconditional stay on arbitral awards if it is established that the award is given on the basis of any sort of fraud.

These are some of the changes which are brought by way of these amendments, there has been an attempt to try and improvise the process of arbitration, but it is a developing process and there are challenges for the same.

Some of the challenges include the mentality of the people, ineffective laws and lack of knowledge of the people.

There are some ways which can be adopted to overcome these challenges, like creating awareness among people so that they might go for arbitration and try to change their thinking and open up to these alternative mechanisms, introducing laws which are more effective will also help strengthen the bridge between the people who want to go ahead with arbitration and the actual process.

\section{INTRODUCTION}

A rbitration is an alternative approach that can be used to resolve certain matters, this provides for an alternative pathway for dispute resolution.

Arbitration is one of the alternate dispute resolution mechanisms, they provide for a way to resolve certain matters without having to go through the rigorous regular process of court proceedings, it provides a basis for a new development in the society, a development where some burden may be taken off of courts and where the society opens up to and accepts these alternative mechanisms to resolve certain disputes.

In arbitration, the respected interested parties, with their free consent choose to submit their matter before an arbitrator, an arbitrator is a neutral third party which decides on the the subject at hand and draws a conclusion, and grants awards accordingly, these awards are known as the arbitral awards.

These awards can be challenged under section 34 (2) of Arbitration and Conciliation Act 1996, grounds like invalidity of arbitration agreement, inconsistency of award with the public policy render an arbitral award prone and vulnerable to challenge according to the said section.

This process demands lesser time, lesser resources and is less rigorous than the regular court proceedings, it is a confidential process and a reasonable conclusion is drawn in a comparatively shorter amount of time.

The proceedings for arbitration are as follows-

An arbitration clause or agreement is present, then the parties have to appoint arbitrator and by virtue of arbitration and conciliation act 1996 they can appoint any arbitrator, but if the 
parties are unable to decide the number of arbitrators within the time span of 30 days, then they can approach the arbitration tribunal which will then appoint a sole arbitrator, further section 21 of the arbitration and conciliation act 1996 talks about commencement of arbitration, a notice on the request of arbitration will be sent to the respondent and the date on which respondent received the notice till the date he can reply to the notice, then arbitrators are appointed by way of section 11 of arbitration and conciliation act, further according to section 23 of arbitration and conciliation act 1996, there must be a time span given to the parties so that they can put forth facts and claim remedy, in this time span, the parties have to submit the statement of claim by providing all the documents backing the facts of the dispute of the arbitration, further comes the part where hearing of parties takes place, first is the preliminary stage, after appointing an arbitrator, in this stage issues are heard and there is information is communicated.

Then, comes the hearing stage in this stage, the parties present the case before the arbitrator.

Further, comes the awards stage, after the completion of all the hearings, the arbitrator specifies that no more evidence will be presented and the hearing is closed and they fix the date for the award and arbitrator provides written award and outcome and conclusion of the arbitration is sent to the parties respectively.

Arbitration law in India is governed under the arbitration and conciliation act 1996, the earlier existing provisions with respect to arbitration like the arbitration act 1940, the arbitration act 1937 and the foreign awards act 1961, came to be repealed by the arbitration and conciliation act 1996.

Although arbitration is a promising alternative mechanism, not all disputes can be handled by way of arbitration and therefore there is a certain category of disputes which can be resolved by way of arbitration.

Disputes like insolvency, intellectual property rights, fraud, criminal cases and guardian matters are some of the dispute which cannot be decided by way of arbitration and they need to be decided upon by respective courts.

There is a requirement for arbitration, as mentioned, it is a process which consumes less time and resource and produces a reasonable conclusion comparatively earlier, it is confidential, it marks a departure from the rigorous procedures of the court.

With every civil matter going before the court, the courts have come to be overburdened and there are many who wait for their matters to be heard and they await the resolution in a shorter span.

Alternative dispute resolution mechanisms provide for this, they provide for an alternative pathway that one can approach and knock the doors with respect to certain matters, it decides on matters in a shorter span and it will help with this issue of courts being overburdened as when certain cases are dealt with by way of arbitration and the time is people become adapt to it and they themselves start going for arbitration, then this overburden of courts, especially with respect to disputes which are within the ambit of the arbitration's legal capacity to decide on, can be lessened and other matters which actually compulsorily need to be heard by the courts, the attention of the courts can shift to those matters, at the same time the interest of the other people who have disputes which can be decided on by way of arbitration, also get a platform where they get a form of a speedy trial and a reasonable conclusion in a shorter span with lesser spent time and resources.
By promoting alternative dispute resolution mechanism, the interest of different parties are adjusted with one another, the interest of the party whose dispute has to be decided by courts only and the interest of the party whose dispute can be decided by way of arbitration, both of them get a fair chance of having the dispute resolved and both of them can have resolution and justice delivered sooner rather than later.

But, obstacles in way of promoting and excepting arbitration prevents this and hence the issue of course being overburdened and several people awaiting justice, eager to have their issue raised and resolved.

These hindrances are in the form of the mentality of the people who are not open to arbitration, they hesitate because they still prefer to go to court and have the matter heard only by a court. This thinking needs to improve, because only with the mindset change will change in the society be brought about, and this issue of courts being overburdened will be dealt with.

There are people who do not want to approach arbitration and then the people who wish to approach arbitration but are unable to do so because of certain obstacles in their path by way of certain procedures and laws which put some sort of a barrier in their way preventing them from availing the benefits inferred by arbitration.

For instance, people go for arbitration but then the extent of judicial involvement makes it difficult for the people to completely trust and put their faith in arbitration because they will always find themselves being inclined towards opinion of the judiciary, failing to test and be satisfied with the work of the arbitration process alone individually.

People are not aware of such mechanisms because they do not wish or do not have the means to be aware of such changing scenarios, hence it is important that they are bought within this ambit of knowledge so that they know that they have an alternative platform that they can approach to have the matter heard and decided on in a shorter time with lesser resources spent.

These hindrances in the form of the orthodox thinking, barricades in the form of procedures or laws, lack of awareness make it difficult for arbitration to completely rise of the top and be the people's first choice for the matters which the arbitration process is competent to deal with.

Though these obstacles can be dealt with, by making effective laws, by creating awareness, by making arbitration mandatory in certain cases because unless and until it is mandatory they will always be a fraction of people not willing to go for arbitration, to reduce the judiciary's involvement to let the people test arbitration for themselves to have their own answer.

However, it is a work in progress and there has been major amendments which have brought in major improvements in the process of arbitration, may to be with respect to the arbitral awards or the qualification of arbitrators or the time limit for arbitration or the arbitral institutions which are set up which are to be graded by arbitration council, and the para metres of such grading, such exhaustive and detailed things are mentioned and dealt with by way of the recent amendments in the act, which do provide for a promising hope for the rise of arbitration in India, but yet with the change of time certain improvements and modifications are always needed.

Some of the major changes brought by way of amendments are also beneficial for uplifting and promoting arbitration so that 
more and more people are convinced with this form of dispute resolution.

\section{The Arbitration and Conciliation Amendment Act 2015 :-}

Some of the features of this amendment for that :-

It laid down that certain sections would be applicable to international commercial arbitration as well, such as section 9 which talks about the grounds for interim measures, section 27 which talks about the arbitral tribunal seeking court assistance with respect to procuring certain evidence such as personal details of the parties and arbitrators, section 37 (1) (a), which deals with the appeals when the parties are not referred to arbitration under section 8 and section 37 clause 3 which specifies that there is no right to a second appeal, not affecting any right of any party to appeal to the Supreme Court. [1]

These sections were also made applicable to international commercial arbitration and by way of the 2015 amendment act. In Barminco Indian underground Mining services V Hindustan Zinc Limited, it was held that since the parties are of Indian nationality, this does not squarely fall within the ambit of international commercial arbitration. [2]

Section 2 (1) (f) of arbitration and conciliation act 1996 defines international commercial arbitration as an arbitration which is with respect of disputes where at least one of the parties who is either by virtue of nationality or by residence in any other country other than India or any body or association which is incorporated or managed in any other country besides India.

Section 9 was amended to say that arbitration proceedings need to commence within 90 days of the interim order passed by the court, and that the court shall entertain application under section 9 only if the remedy under section 17 will not be sufficient in that particular circumstance.

In Good will nonwoven Limited V Xcoal energy and resources 2020, the Delhi High Court held that for granting interim measures under section 9, it is not a prerequisite mandate that the parties must have assets within the territory of India. [2]

Section 14 was amended which bridge the gap between the earlier provision and the amended one, the earlier provision only provided for termination of the arbitrator but the amended provision also provides for substitution of the terminated arbitrator by another.

In, Jayesh H. Pandya V Subhtex India Ltd 2019, in this ruling of the Supreme Court, it was held that an arbitrator has no power to delay and go beyond the agreed time limit, without the consent of the parties to the dispute, this time limit cannot be extended by the arbitrator. [3]

The amendment to section 17 laid down that the arbitral tribunal under section 17 would have the same power as a court with respect to passing interim orders.

In the earlier provision, arbitral tribunal was not empowered to pass interim orders and they were not enforceable, but this was changed by way of this amendment.

In Sundaram Finance Ltd V P. Sakthivel 2018, it was said that the arbitral tribunal has the power to grant interim relief, the same way a regular court has the power to do so under section 9 of the said act, the arbitral tribunal is well within its authority to issue an interim order for securing certain amount for the dispute with respect to the arbitration and can also order interim measure of production at its discretion, it was also laid down in a very clear manner that arbitral tribunal has the power to grant interim relief. [4]

The amendment to section 24 makes a requirement for the arbitral tribunal to hold hearings on a daily basis and also makes it mandatory for the arbitral tribunal to not grant adjournment unless it is necessary.

This amendment provides for a sort of a speedy process for dispute resolution as unnecessary adjournments won't be granted and hearings held on a daily basis will put the entire process on a comparatively faster track.

Section 29A and 29B have been added which provide for time bound arbitration, this deals with the basic criticism with respect to arbitration, that it is a very lengthy process, but, codified sections which provide for time bound arbitrations concretise the fact that arbitrations will be put on a time bound scale and will be dealt with within the appropriate time sphere and won't be delayed with any unjust cause.

However, the time can be extended by six months by the consent of the parties or if the court extends it, otherwise the mandate of the arbitrator is terminated.

In Senbo Engineering Limited V Hoogly River Bridge Commissioners, the bench of the Calcutta High Court said that there is no official ban or restriction on approaching any court for extending the time under section 29A of the act, more than once. [5]

In DDA v. Tara Chand Sumit Construction Company, the court held that an application under section 29A of the said act to extend the mandate of an arbitrator would be before the court which has the power to appoint an arbitrator under section 11 of the arbitration act in the first place. [2]

Amendment to section 34 laid down that an award which is passed in international arbitration can be set aside only if it is against the public policy of India or if it is impaired by fraudulent means or by way of corruption or against any fundamental policy of the Indian laws or if whether it is against morality and justice.

In The Project Director National V M. Hakeem 2021, a bench consisting of Justice Rohinton Fali Nariman and Justice BR Gavai, made the law clear and held that the court has no power to modify an award which is passed under section 34 of arbitration and conciliation act 1996. [6]

Section 36 was amended which laid down that an award will not be stayed just by way of filing an application for setting aside an award under section 34 but rather a specific order from the court staying the execution of that arbitral award on application made for the said purpose by one of the parties is a requirement In Noy Vallesina Engineering SpA V Jindal Drugs Ltd, the Supreme Court held that a challenge to foreign awards is not maintainable under section 34 of arbitration and conciliation act 1996. [7]

The Arbitration and conciliation Amendment Act 2019:-

Some of the changes brought by way of this amendment are as follows -

The term arbitral institution has been introduced and defined. These arbitral institutions are to be designated by the High Court or the Supreme Court, by way of section 11 (3A) of the act.

Appointment of arbitrators under section 11 of the said act, this amendment empowers the Supreme Court in case of international commercial arbitration and and High Court in case 
for arbitration other than international commercial arbitration to designate the respective arbitral institutions, these arbitral institutions are to be guided by the arbitration council of India.

This amendment also provides for what is to be done if a graded arbitral institution is not available or in the absence of a procedure to appoint an arbitrator.

Part $1 \mathrm{~A}$ is established, section 43A-43M, lays down that arbitration council of India will be established by central government notification, they will have their headquarter placed at Delhi and the amendment also specifies the composition of the Arbitration Council of India.

The functions vested upon the council are to promote and encourage these alternative dispute resolution methods, frame policies and regulations for establishing and maintaining the professional standards which are required for these alternative dispute resolution mechanisms and for grading the arbitral institutions and the arbitrators.

The factors for grading are also specified, certain para metres like the calibre of the arbitrators, the performance of the arbitrators, the infrastructure of the arbitral institution, the quality of the arbitral institution, their compliance with respect to time limits for arbitration will also be taken into consideration.

Time limit with respect to completion of the arbitration proceedings, granting arbitral award and extension of time is also specified under section 23 (4). [8]

In Shaf Broadcast Limited V Doordarshan, a 3 judge bench held that the arbitration proceedings have to be completed within 12 months. [9]

The general norms which are to be followed strictly by the arbitrators, norms such as being impartial and neutral, consistent with various laws justice and equity and capable of granting a reasonable arbitral award to the parties.

An arbitrator being unfair and inclined towards one party and giving and unreasonable arbitrary award fails the entire purpose of arbitration and puts the other party at a disadvantage, it is very crucial that the arbitrator is impartial and neutral and grants a just and reasonable arbitral award, these norms are to be strictly adhered to.

In Vinod Bhaiyalal Jain Vs. Wadhwani Parmeshwari Cold Storage Pvt. Ltd, the Supreme Court set aside an arbitral award because of bias against the arbitrator, with respect to him awarding an uninfluenced and impartial award.

Supreme Court held that there should not be any bias against the arbitrator. [10]

According to section 42A, Confidentiality of the arbitrator, the interested parties and the arbitral institution must be protected, only exceptional case where with respect to enforcement of the arbitral award disclosure is required, otherwise the confidentiality is to be protected in totality.

The Arbitration and conciliation amendment act 2021 :-

Some changes brought by way of this amendment are as follows -

The qualifications of the arbitration is proposed to be prescribed by the arbitration Council of India.

If an award is given on fraudulent agreement on corruption, then the court shall be empowered to grant unconditional stay as long as an appeal under section 34 of the arbitration law is pending.
This amendment lays down certain para metres and norms that are to be followed by the arbitrators in an altogether a separate schedule, some of the requirements under the said schedule include that the arbitrator must be an advocate under the advocates act 1961 with 10 years of experience or an officer of the Indian legal services.

And the general norms which would be applicable to arbitrators or that they should be well versed with the Indian Constitution. [11]

\section{CONCLUSION}

Arbitration provides for another way for dispute resolution, one that marks a departure from the rigorous procedure of court proceedings, in this process a neutral third party is appointed known as the arbitrator before which the issue at hand is put, the arbitrator comes to a conclusion and rewards a reasonable arbitral award.

Courts are overburdened by numerous cases, and this results in delayed justice and dispute resolution, hence it is a factor which negates the situation and hence arbitration provides far away where the court's burden can be reduced and certain cases which fit the criteria of the disputes which arbitration is empowered to decide upon, such disputes can be settled by way of arbitration so that other disputes which actually need only the court's decision to resolve, the attention of the court's can be diverted to such cases and other cases which can be settled by way of arbitration shall be put forth accordingly before an arbitrator.

For a society to move forward, the interest of multiple parts of the society have to be adjusted, similarly in this way if arbitration is promoted then the interest of different parties are adjusted accordingly because the disputes which can be resolved by arbitration will be put before an arbitration process and hence arbitration will act as a platform for the dispute resolution of such matters and the other matters which arbitration cannot decide upon and only the courts can, such matters will also have a platform before the courts and the courts burden will be reduced, which will be very effective and beneficial.

Arbitration in India is governed by the arbitration and conciliation act 1996, with time, the process has evolved to have India take a step further into becoming an arbitration hub where arbitration is highly promoted and is on increasing level being opted by many people for the dispute resolution, by way of amendment the process involved immensely so as to strike a balance between the procedure and the party's interest and to make sure that neither are compromised and keeping both of them at an arms length and in a proper balanced scenario, and concluding it with a reasonable arbitral award, without any unfair means.

These amendments have helped to evolve the process of arbitration, from such amendments which bridge the gap between the previous and the amended provisions, to placing a time barrier on arbitration to have a fruitful outcome as soon as possible without any undue delay, to an extent that even unnecessary adjournments are advised against, search major changes have been brought about by way of the amendments, however it is still a developing process and people are still a work in progress for accepting it in totality so as to go ahead with it with respect to all the matters which are subject matter of arbitration. 
There are various barriers in the promotion of arbitration process in India, some of them are the mentality of the society which still believes that the best way to resolve any dispute is only to approach a court and have a court decide upon it, they refuse to change the thinking and believe that there could be another way which would turn out to be as fruitful as the court of law, people still hesitate to go to arbitration specially for matters which have a huge stake for example any business matter with a very huge financial risk or steak, people would always prefer going before a court for the resolution of such matters because it is the courts that they trust.

On the other hand there are also people who may want to opt for arbitration but are unable to do so due to some or the other reason, maybe due to some gaps in the provision which make it difficult by placing a barrier before someone who wants to approach arbitration.

Many people are still not aware that such alternative dispute resolution methods exist, there are many people who need to be made aware of such things, they can only avail the benefits provided by such alternative dispute resolution methods if they know that these methods exist.

Judiciary's involvement is another challenge in some cases because as it is people are always inclined towards the courts, and those people who try to opt for another method, find themselves in a situation where the judiciary's involvement is at a very great extent comparatively and it is very likely that people tend to get inclined towards the opinion of the judiciary, this again does not provide them with a chance to actually test the process of arbitration and completely placed their faith upon it because judiciary's involvement is at an extent which is enough to make people inclined towards it, and people may tend to undermine the ongoing arbitration process and be inclined to the opinion that the courts hold.

In White industries V Republic of India, one of the major issues raised was the involvement of the judiciary and it was agreed that the involvement of the judiciary should be kept at the very minimum scale.

There are ways that these challenges can be met with, awareness needs to be created so that more and more people are made aware of such alternative dispute resolution methods so that they can when in need opt for it, making arbitration mandatory may also be an effective solution because until and unless such a mandate is placed they will always be a fraction of people who would want to avoid it and go ahead with the regular court proceedings to settle the dispute because of the already existing faith and trust that they have in the court process, this denies them an opportunity to build faith on the process of arbitration.

Reducing the judiciary's involvement so as to give people a real chance to place the entire belief on arbitration and see for themselves how fruitful it turns out to be for them, filling the gaps between provisions, as done in the 2015 amendment act with respect to section 14 where the the gaps between the earlier provision and the amended one was bridged by providing for substitution of the arbitrator in the amended provision, such changes need to be made for establishing more effective laws and giving people a more effective legislative provision to rely on.

\section{ACKNOWLEDGEMENT}

I have taken efforts in this research, however it would not have been possible without the help and support of my guide, Dr. Deepti Khubalkar.

I would like to thank my guide and institute, Symbiosis Law School Nagpur, for providing me with the support and guidance necessary to do this research work.

I am grateful to my guide for her guidance which has sustained my efforts throughout.

I would also like to thank others for their support and encouragement.

I sincerely thank them for helping me to the best of their abilities.

\section{REFERENCES}

[1] https://singhania.in/blog/highlights-of-amendment-to-the-arbitration-andconciliation-act-1996-via-arbitration-ordinance-2015

[2] https://www.argus-p.com/papers-publications/thought-paper/significantjudgments-on-arbitration-and-conciliation-act-1996-may-2020-to-july2020/

[3] https://indiankanoon.org/doc/16310262/

[4] https://indiankanoon.org/doc/143613156/

[5] https://indiankanoon.org/doc/168019779/

[6] https://indiankanoon.org/doc/98965625/

[7] https://www.mondaq.com/india/trials-appeals-compensation/1022526/aforeign-award-cannot-be-challenged-under-34-of-the-arbitrationconciliation-act-1996-supreme-court-of-india--noy-vallesina-engineeringspa-v-jindal-drugs-ltd-ors

[8] https://www.mondaq.com/india/arbitration-dispute-resolution/840292/thearbitration-and-conciliation-amendment-act-2019-key-highlights

[9] https://www.scconline.com/blog/post/2019/12/25/2019-scc-vol-10december-14-2019-part-3/

[10] https://indiankanoon.org/doc/52626671/

[11] https://www.scconline.com/blog/post/2021/03/16/arbitration-andconciliation-amendment-act-2021/

\section{AUTHORS}

First Author - Milind Chopra, Qualification :- 2nd year Law Student, BBA LLB., Institute :- Symbiosis Law School, Nagpur. Email Address :- chopramilind28@gmail.com 